\title{
Electronic Word of Mouth During Adaptation Pandemic Covid-19 Towards the New Normal: Cases in Indonesia
}

\author{
Novi Andayani Praptiningsih ${ }^{1}$ \\ Communication Department, Social and Political Science Faculty, \\ University of Muhammadiyah Prof. Dr. HAMKA (UHAMKA) Jakarta 12510, Indonesia
}

novi.ap@uhamka.ac.id

\begin{abstract}
In this digitalization era the role of e-WoM is very useful especially during the conditions of the Covid- 19 pandemic outbreak. Electronic Word of Mouth (e-WOM) is a form of marketing communication that contains positive or negative statements made by potential customers, customers or ex-customers about a product or company Large-Scale Social Limitation Policy (PSBB) in a number of regions in Indonesia in order to cut off transmission corona virus is driving skyrocketing use and demand for online transaction services because when the Covid-19 pandemic emerged, almost all human activity was restricted. The policy plan for the implementation of new normal in Indonesia due to economic reasons is slowing, there are still many concerns of some Indonesian people because many are lacking discipline by not heeding health protocols, such as keeping a distance, not crowding, using masks, and washing hands / handsanitizer. Always think positively and adhere to the health protocol of the pandemic period as a solution to community members not easily infected by the covid pandemic 19 epidemic that has not yet gone and become extinct from Indonesia and the world. Even though the activities that have to run are not normal, we can still take lessons from the events behind this pandemic. The main key to success in facing this pandemic is to always be optimistic and think-behave-behave positively.
\end{abstract}

Keywords: electronic word of mouth, adaptation, covid 19, new normal.

\section{INTRODUCTION}

The impact of the corona virus pandemic (covid 19) has greatly weakened the business world and the economy in Indonesia and even the world. In a relatively short time, the marketing pattern also changed, especially when social distancing was implemented through Large-Scale Social Restrictions. In the new normal era, all activities are running back to normal while still following health protocols, but there are still many people who have low discipline, as evidenced by crowds in public areas [1]. In this pandemic situation, business people rack their brains by optimizing online marketing and digital branding as a means of communication with their target consumers, starting from focusing on digital marketing through social media, collaborating with online motorcycle taxis, forming reseller teams, to word of mouth and electronic word. of mouth.

The development of information and communication technology has now changed society and its environment. The emergence of this technology has an impact on media changes known as new media, which is a media that is the result of integration or a combination of several aspects of combined technology, including computer and information technology, communication networks, and digital media and information messages. The concept of the 
development of new media cannot be separated from the emergence of the Internet and the World Wide Web due to the globalization of information technology. Social media is a media where users can easily participate in, share and create messages, including blogs, social networks, online wikis or encyclopedias, virtual forums, including virtual worlds.

According to Hennig-Thurau et al., [2], Electronic Word of Mouth (e-WOM) is a form of marketing communication that contains positive or negative statements made by potential customers, customers or former customers about a product or company, which available to many people or institutions through the medium of the Internet. In the online world there are various ways in which consumers can exchange information. Internet users can conduct Electronic Word of Mouth through a variety of online channels, including blogs, microblogs, e-mails, consumer review sites, forums, virtual consumer communities and social networking sites. In reflecting on the feeling of pleasure and satisfaction from consumers, it will be directly proportional to a positive image view for the product or brand.

The Electronic Word of Mouth The Internet has enabled the emergence of new forms of communication platforms that can better empower providers and consumers, enabling them to share information and opinions from both Business-to-Consumer, and from Consumer-to- Consumer. Electronic word-of-mouth (eWOM) refers to any positive or negative statement made by potential customers, actual customers, or former customers about a product or company, which is available to many people and institutions via the Internet [2]).

Gruen [3] defines e-WOM as a communication medium for sharing information about a product or service that has been consumed between consumers who do not know each other and have met before. The advancement of internet technology has made the position of WoM which used to be relied upon by many to begin to shift. Today's consumers are starting to rely more on e-WoM in the process of finding information before buying a product. Thus, the strategy setting of the remarketing practitioners is again related to who the target consumers are because not everyone can be exposed to the WoM and e-WoM strategies. If the target is wrong, then communication from the company to consumers will be ineffective and will have an impact on the low consumer buying interest [4].

Electronic word of mouh communication refers to the exchange of comments, thoughts or ideas between two or more consumers, neither of which is a source of marketing. Jimenez and Mendoza [5], show that eWOM has an influence on consumer behavior before consumers decide to buy a product or service. Electronic word of mouth (e-WoM) communication refers to positive or negative statements made by potential, actual, or former customers about a product or company, which is available to many people and institutions via the Internet [6]. The four main dimensions identified to measure e-WoM are: first, intensity (activity, frequency, dispersion. Second, positive valence (praise). Third, negative valence. Fourth, content [7].

\section{DISCUSSION}

The condition in which the corona virus (covid 19) is endemic not only in Indonesia but also in the world, forcing everyone to stay at home, and isolating themselves so that they can avoid the corona virus, causing activities to be hampered. Even now, largescale social restrictions have been implemented in several areas, especially in the red zone category. In this era of digitalization, the role of e-WoM is very useful especially with the current Covid-19 pandemic conditions. Large-Scale Social Restriction Policies in a number of regions in Indonesia in order to cut the transmission of the corona virus have driven the skyrocketing use and demand for online transaction services because when the Covid-19 pandemic emerged, almost all human activities were limited. Online transaction activities have increased drastically, be it shopping through the marketplace, e-commerce, or ordering food and beverages through delivery applications. In this pandemic era, of course, we never wanted the conditions to be like today, where activities were limited, plans that had been prepared could no longer be implemented, meetings were substituted with digital media applications.

The role of e-WoM during a pandemic helps facilitate activities in fulfilling daily life, such as shopping because many malls and shops are closed, and restaurants only serve take away and delivery messages either through courier services or online motorcycle taxis / taxis.

Taxi Bluebird also provides message services for goods and food during this pandemic without carrying passengers, namely Bluebird COD (Chat-OrderDelivery), where consumers place orders through the MyBluebird application (ikiranrakyat.com, accessed May 17, 2020).

Thus it is evident from the fact that e-WOM is now considered the most dominant factor influencing consumers. Understanding e-WOM is very important during a pandemic to reach global audiences quickly and easily. Especially with this pandemic, activities such as shopping, teaching and learning, communicating and even business activities must now move to the digital realm. People must quickly and readily adapt to these circumstances and must carry out an online marketing strategy. This step is important, not only so that 
companies can continue to operate during a pandemic, but also for long-term success in a digital-based era. Fortunately, nowadays business transformation from offline to online is getting easier. There are at least three channels for online sales activities that can be used. First, have your own website. Second, you can start opening shops and selling through marketplace platforms such as Tokopedia, Shopee, Bukalapak, and others. Third, communication applications such as Instagram and Whatsapp Business make it easier for sellers to deal directly with consumers in processing transactions. With the aforementioned options, anyone can practically start selling online, even without the need for proficiency in the IT field.

Jones [8] states that users of social networking sites have an important role in the process of searching for information before consumers decide to buy a product or service. Goldsmith and Horowitz [9] state that the use of the internet has changed the way consumers communicate and various opinions or suggestions regarding products or services that have been consumed. The process of communication between consumers via the internet is known as the Electronic Word of Mouth (e-WOM). Research conducted by Jimenez and Medoza [5], shows that e-WOM has an influence on consumer behavior before consumers decide to buy a product or service. Advances in information technology have caused more and more consumers to seek information needed for a product before making a purchase, such as through Open rice.com (review sharing platform), Tokopedia (online shop), KASKUS (Online community), blogs, and Instagram. In fact, many people acknowledge very well that e-WoM marketing is an effective and attractive marketing strategy because it overcomes resistance from consumers, does not require high costs and is a fast messaging process especially through social media.

According to Kotler and Keller [10], there are three characters in word of mouth both online and offline, namely: First, Influential (influential). People believe in people they know and respect, so word of mouth can really influence. Second, Personal (personal). Word of mouth can be an intimate dialogue that reflects personal facts, opinions and experiences. Third, Timely (on time). Word of mouth occurs when people want and are interested in doing it, and often follow with events or experiences that are important or meaningful. [10]. Even in the world of education, when prospective students are looking for scholarship references or further study abroad, they also consider word of mouth that goes beyond advertising. Euro Management word of mouth affects students' interest in continuing their studies in Germany. The correlation of the Euro Management word of mouth variable on students' interest in continuing their studies in Germany is strong [11].
According to Babin, Barry J., Yong-Ki Lee, Eun-Ju Kim, Mitch Griffin about Modeling Consumer Satisfication And Word Of Mouth Communication: Restorant Petronage Korea. Journal of Service Marketing Vol. 19 No. 3, that the indicators of Word Of Mouth Communication are: first, discussing someone's willingness to talk about positive things about product quality to others. Consumers expect maximum satisfaction and have interesting material to talk about with people. Second, recommending that consumers want products that can satisfy and have advantages over others, so that they can be recommended to others. Third, encourage friends or relations to make transactions on products and services. Consumers want attractive feedback when influencing other people to use the product or service that has been announced [12].

One of the studies on Islamic insurance is related to the influence of electronic word of mouth (e-WoM) and conventional media on subjective norms and intentions to buy Islamic insurance on 458 Indonesian Muslim clients who are members of the online community and also holders of Islamic insurance policies in the three largest cities in Indonesia. Indonesia: Jakarta, Semarang and Surabaya. Research shows that e-WoM and conventional media can influence subjective norms. In addition, subjective norms have a significant effect on purchase intention among Islamic insurance policy holders [13].

The results of research by Torlak, cs [14] show that there is a significant positive relationship between electronic word of mouth on brand image and mobile phone purchase intention among young Turkish consumers. Chu, cs [15] concluded that the 'Circle of Friends' on WeChat has helped make e-WoM more accessible. Research on consumer engagement and eWOM, related to the influence of personality, sense of belonging and the need for self-improvement. The results showed that the need for self-improvement positively influenced Chinese tourist engagement through WeChat. In addition, a partial positive relationship between consumer engagement and e-WOM intention has been identified that only dedication to WeChat is directly related to travelers' intentions to engage in e-WOM on WeChat. Dedication was found to mediate the influence of need for self-improvement on e- WOM intention. The sense of belonging, however, does not have a significant impact on consumer engagement [15].

Everyone's response to such situations varies. There are those who complain that they cannot adapt to this situation, besides that there are also those who are able to make peace with the situation and spread optimism to the surrounding environment. The adaptations that exist in the use of online media as a result of the corona virus pandemic take various forms. There are people who actively use online media as a place to sell them 
positively. On the other hand, online media is also used for negativity and meeting lifestyle needs. There are those who adapt quickly to digital and some are slow due to a lack of digital knowledge and skills. This pandemic requires people to adapt quickly to new work patterns. Even though the activities that must be carried out are unusual, we can still take lessons from the events behind this pandemic. One of the main keys to success in facing this pandemic is to always remain optimistic and think positively.

\section{CONCLUSION}

In this era of digitalization, the role of e-WoM is very useful, especially during the Covid-19 pandemic outbreak. Large-Scale Social Restriction Policies in a number of regions in Indonesia in order to cut the transmission of the corona virus have driven the skyrocketing use and demand for online transaction services because when the Covid-19 pandemic emerged, almost all human activities were limited. The policy plan to implement the new normal in Indonesia due to economic slowdown reasons is still a lot of concern for some Indonesians because many are less disciplined by disregarding health protocols, such as maintaining distance, not crowding, using masks, and washing hands / handsanitizer. Always thinking positively and obeying health protocols during the pandemic is a solution for community members who are not easily infected by the COVID-19 pandemic that has not yet been extinct.

\section{REFERENCES}

[1] ibtimesid, .

[2] T. Hennig-Thurau, K. P. Gwinner, G. Walsh, and D. D. Gremle, "Electronic word-ofmouth via consumer-opinion platforms: What motivates consumers to articulate themselves on the," Internet J. Interact. Mark., vol. 18, pp. 38-52, 2004.

[3] T. W. Gruen, T. Osmonbekov, and A. J. Czaplewski, "eWOM: the impact of customer-tocustomer online know-how exchange on customer value and loyalty," J. Bus. Res.-456, 2006.

[4] T. W. Andrew, "Pengaruh word of mouth dan electronic word of mouth terhadap purchase intention: sebuah studi kasus mengenai perilaku konsumen terhadap jasa ojek online Gojek," $J$. Bisnis Dan Manaj., vol. 53, no. 12, pp. 241-253, 2016.

[5] F. R. Jiménez and N. A. Mendoza, Too popular to ignore: The influence of online reviews on purchase intentions of search and experience products.Journal of Interactive
Marketing,27(3),226-235. 2013.

[6] M. R. Jalilvand, N. Samiei, and S. H. Mahdavinia, "The Effect of Brand Equity Components on Purchase Intention: An Application of Aaker's Model in the Automobile Industry," Int. J. Bussines Manag., vol. 2, p. 2, 2011.

[7] Goyette, "e-WOM Scale: Word-of-Mouth Measurement Scale for e-Services Context," Can. J. Adm. Sci., vol. 27, pp. 5-23, 2010.

[8] B. Jones, Entrepreneurial marketing and the Web 2.0 interface,Journal of Research in Marketing and, no. ip,12(2). 2010.

[9] R. E. Goldsmith and D. Horowitz, Meas. Motiv. Online Opin. Seek. Interact. Advert., vol. 6, no. 2, pp. 3-14, 2006.

[10] P. Kotler and K. L. Keller, Marketing Management, 14e. England Pearson Education Limited, 2012.

[11] N. A. Praptiningsih, "The Effect of Word of Mouth on Student Interest Study to Germany Through Euro Management," J. Perspekt. Komun., vol. 3, no. 1, pp. 23-29, 2019.

[12] B. J. Babin, Y.-K. Lee, E.-J. Kim, and M. Griffin, "Modeling Consumer Satisfication And Word Of Mouth Communication: Restorant Petronage Korea," J. Servive Mark., vol. 19, no. 3, pp. 133139, 2005.

[13] U. Amron and A. Mursid, "The role of electronic of word mouth, conventional media, and subjuctive norms om the intention to purchase Sharia insurance services," J. Financ. Serv. Mark., vol. 23, pp. 218-225, 2018.

[14] O. Torlak, B. Y. Ozkara, M. A. Tiltay, H. Cengiz, and M. F. Dulger, "The Effect of Electronic Word of Mouth on Brand Image and Purchase Intention: An Application Concerning Cell Phone Brands for Youth Consumers in Turkey," J. Mark. Dev. Compet., vol. 8, 2014.

[15] S. C. Chu, H.-H. Lien, and Y. Cao, . "Electronic of word mouth (eWOM) on WeChat: examining the influence of sense of belonging, need for selfenhancement, and consumer engangement on Chinese travellers' eWOM," Int. J. Advert., vol. 2019, no. ue 1, pp. 26-49, 2018, doi: 10.1080/02650487.2018.1470917. 